\title{
食品, 料理の栄養学的係数表現法に関する研究 $(X)$ Studies on Nutritional Coefficient of Food (Part X)
}

\author{
栄養係数による学校給食献立の解析 \\ Nutritional analysis of school lunch menu by use of the \\ method of nutritional coefficientification
}

(昭和 38 年 12 月 14 日受理)

藤 原 邦 達 福 原 貞 介
(Kunisato Fujiwara)

\begin{abstract}
The method expressing the nutritional quality of food and dishes as coefficients has been developed in our latest 9 reports.

Consequently the menu concerning the school or factory lunch has became nutritionally analysable much easily by the use of the authors' concepts about (1) F. N.C, (2) E. N.C, (3) N. B.C. and its figure, (4) qualitative level of protein, and (5) amino acids balance.

The menu of Kyoto City school lunch was analysed in this report.
\end{abstract}

これまで，過去 9 報において，食品料理の栄盖学的価 値を係数として表現する方法を開発してきた。

その結果 (1) E. N. C. (2) F. N. C. (3) N. B.C. 扰よ びその図法, (4)蛋白質のレベル，(5)アミノ酸平衡性に関 するわれわれの開発した諸概念を用いて, 学校, 工場給 食の献立が栄盖学的により容易に解析可能となった。

本報では京都市学校給食献立をとりあげることにし た。

一般に学校, 工場などの集団給食やさらに家庭食の献 立を栄養学的に解析評価するばあい, 基本的には次の諸 点に着目せねばならない。

(1) 栄養基準量との関係

(2) 経済栄羡性

（3）栄養素間平衡性

(4) 蛋白の質的水準

(5) $ア ミ$ ノ酸平衡性

(6) ビタミン，ミネラルの基準

これらの5ち従来は主として(1)項以外が十分に検討さ れていたとはいえなかった。その理由としてはまず諸概 念を適切に数量, あるいは図式化する方法が十分開発さ れていなかったことがあげられるし，さらに簡易な計算 法がなかったことなどが考えられる。

われわれはこれまで過去 9 報にわたって，食品料理の 価値を栄養学的に係数として表現する方法を開発する努
力をつづけてきたが，今回，京都市昭和 37 年度学校給食 献立を対象として上記の諸点につき，その栄璘学的実態 の解析を行ならことにした。

従ってこの報告は, 献立の立案, 解析の手法としての われわれの係数論の実用性の真価を問 5 と共に, 具体的 には京都市学校給食の篓養学的内容の一端にふれること をその主な目的とするものである。

\section{解析の方法}

1. 栄養所要量との関係対比

現行の献立表では, 各項目別栄養素の絶対量が g, I. U. など，諸単位を付して列記されている。これを F. N. C.， 基礎栄養係数化することによって第 I 報1)に説明した利 点が特徵づけられる。

2. 栄養経済性の数值化

献立の価值はその栄金経済性についても検討されねば ならない。この点についてては第 $\Pi^{2)}$ ，第壮多報において， E. N. C, 経済栄養係数として論じた通りである。集団給 食のように予算に制限のあるばあいには、コストが低く 栄養価の高い献立を開拓するために E. N.C. の数値に も関心をもたねばならない。

3. 栄養平衡性の数值化

栄養学的に平衡のとれた献立であるかどうかは，各栄 養索の所要量との比率 $f_{x}$ をさらに対比することによっ 


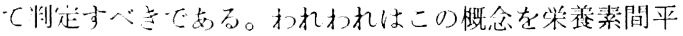
衡係数 $K$ として第 $\mathrm{V}$ 報らに解説した。学校給食に扣いて も個々の策篮素々所要量の対比のほかに, 平衡関係の傾 向についても数値化すべきであろう。

4. 栄差平衡性の図化

前項の数优 $K$ は 2 项栄荃素間の平衡関係を示すもので あったが,ささらに多項目の笨福素について，しかも視覚 的に平衡性を直読するために，われわれは第 $\mathrm{V}$ 報引に拉 いて平衡関倸网法走示した。今後の猒立作製立案に際し ては常に平衡旻形を明示することが望ましい。

5. 连白価算出法り简易化

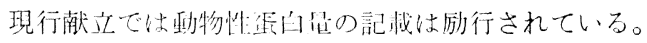
しかし、いうまでもなく正白洒の算定記録を丰施すべき であるにもかかわらず，それが徽底しにくいひとつの理 由として，従来その襸法がかなり煩雑にすぎたことを あげればならない。われわれは第 $\mathrm{VI}^{6)}, \mathrm{VI}^{7)}$ 報に扣い て,これを迅速に決定寸る方法を開発した。

6. アミ八酸平衡性の解析と図化
単に䖽白価の大小だけでなく，必須アミノ酸相互間の 栄租学的平衡関係を献立ごとに明白にして，献立作製の 資料にすべきであって，われわれは第IX報りにおいて， アミノ酸平衡関係図法について説明した。

7. 献立作製能率の向上

一定の基準栄盖量をみたす上うに献立を考案する作業 が害際に行なわれているのであるが,このばあいF.N. C. 法によることが適当であり，さらにとのための F.N. C. 計算尺が考案されることについては第亚報》に説明し たとおりである。本報でる給食献立を実際に用いて京都

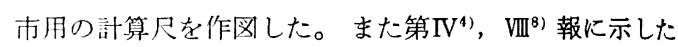
コスト計算尺についても言及する。

\section{解析の実際とその考察}

1. 栄盖所要量との関係対比

文部省保健体育審議会答申による学校給食学童 1 人 1 回あたり栄羡基準量の F. N.C. 值は第 1 表に示すとお りである。

第 1 表 学校給食基準 の F. N.C. 表

\begin{tabular}{|c|c|c|c|c|c|c|c|c|c|}
\hline 度 & 基 準 & $f_{\text {cal }}$ & $f_{\text {prot }}$ & $f_{f a t}$ & $f_{B_{1}}$ & $f_{B 2}$ & $f_{c}$ & $f_{A}$ & $f_{c a}$ \\
\hline \multirow{2}{*}{$\begin{array}{l}36 \text { 年 } \\
\text { 高低学年 }\end{array}$} & & 24 & 36 & 33 & 46 & 46 & 31 & 75 & 84 \\
\hline & 9 〜1才 & 29 & 同，上 & " & 60 & 60 & 同上 & $" \prime$ & $"$ \\
\hline \multirow{2}{*}{$\begin{array}{c}37 \text { 年 } \\
9 \sim 11 才\end{array}$} & & 28 & 39 & 40 & 46 & 46 & 62 & 50 & 66 \\
\hline & 9 〜1才 & 33 & 同 上 & " & 60 & 60 & 同上 & $" \prime$ & $" \prime$ \\
\hline \multirow{2}{*}{$\begin{array}{l}37 \text { 年 } \\
6 \sim 8 \text { 才 }\end{array}$} & & 24 & 33 & 33 & 46 & $\begin{array}{l}46 \\
\ldots \ldots\end{array}$ & 46 & 30 & 50 \\
\hline & 9 〜11才 & 26 & 同 上 & $" \prime$ & 60 & 60 & 同上 & $" \prime$ & $" 1$ \\
\hline
\end{tabular}

次に京都市学校給企献立（以後学給献立と略称）を F. N. C. 化した一例を第 2 表に示す。これを全献立につ いて数值化し月別に平均をとると第 3 表の結果を得た。

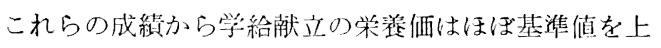
回るものであるがビタミンCに扔いては不良であること がわかる。但しこれも12日以降は改善されている。さら に第 3 表の数值を第 $\mathrm{I}$ 報”の表 3 と対比すると, 学給献 立は特にビタミン等の補給源になっていることが明かで あり，学給の 1 蹎はオムレッライスの 1 食に匹敵する内 容をもっていることも判明する。もちろん単なる栄養価 の比較では必ずしも F. N.C. 表による必要はなく従来 ど扣りの献立表を用いればよい。しかし第 1 表にお。 いて横列の数字の閵係は直ちに平衡性を示するのであり 所要量の記憶を要せずして, 同じウエイトをもって, 例 えばビタミンが強調されている献立であることがわかる のがわれわれの方法の特徴である。またこうした F.N.
C. の数值を用いて以後の解析を進めることができる。

\section{2. 経済栄盖性の数値化}

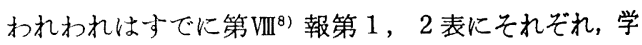
給献立の月別 E. N. C. 表, 京都市内家庭料理 E. N.C. 表を示したが, 料理店料理の E. N.C. より家庭料理の E. N.C. がかなり高く、さらに学給の E. N.C. がより高 いことが明かになった。特に強化食品を自由に選択し， また強化剛を殹使しうる学給献立の $E_{\text {vitam }}$ in の高いこ とが注目される。

一般に $f_{x}$ すなわち献立の栄素係数を上年させると共 に $E_{x}$ 即ち栄養経済係数をも上年させるよ5に努めるた めにこれら数値の記載を励行すべきである。

\section{3. 栄萎平衡性の数値化}

F. N.C. 法による第 2 表の数值を基礎として平衡俰数 $K$ を求めると 4 月， 6 月， 7 月の一部の献立について第 4 表の成績がえられる。 
第 17 巻第 4 号

第 2 表 献立 $の$ 栄㕌係数 化

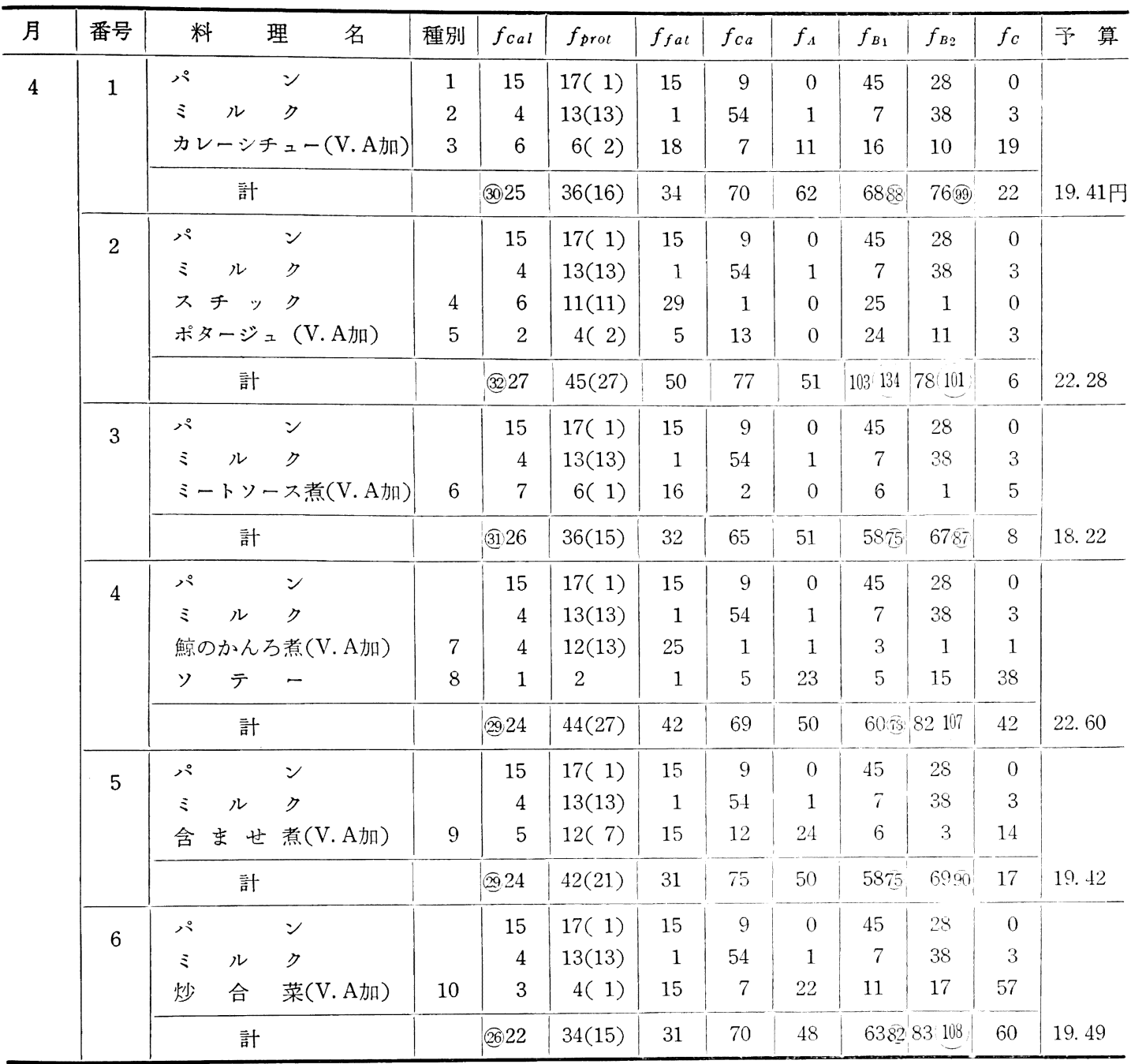

第 3 表 献立の月別平均 F. N. C.

\begin{tabular}{c|c|c|c|c|c|c|c|c|c}
\hline 月 & 回 & $f_{C a l}$ & $f_{\text {prot }}$ & $f_{f a t}$ & $f_{C a}$ & $f_{A}$ & $f_{B 1}$ & $f_{B 2}$ & $f_{C}$ \\
\hline 4 & 9 & 30 & 40 & 39 & 71 & 51 & 68 & 75 & 26 \\
\hline 5 & 12 & 33 & 44 & 53 & 73 & 56 & 70 & 80 & 33 \\
\hline 6 & 13 & 33 & 42 & 54 & 72 & 50 & 70 & 81 & 31 \\
\hline 7 & 7 & 34 & 41 & 59 & 73 & 52 & 70 & 80 & 28 \\
\hline 9 & 10 & 33 & 40 & 55 & 65 & 52 & 71 & 78 & 31 \\
\hline 10 & 15 & 34 & 43 & 51 & 73 & 49 & 71 & 83 & 30 \\
\hline 11 & 15 & 33 & 41 & 57 & 69 & 50 & 71 & 81 & 33 \\
\hline 12 & 10 & 34 & 42 & 51 & 71 & 51 & 71 & 81 & 60 \\
\hline 1 & 9 & 34 & 42 & 56 & 74 & 55 & 73 & 84 & 61
\end{tabular}

\begin{tabular}{c|c|c|c|c|c|c|c|c|c}
\hline 2 & 12 & 34 & 44 & 55 & 77 & 55 & 76 & 86 & 61 \\
\hline 3 & 8 & 34 & 43 & 55 & 71 & 59 & 75 & 92 & 53 \\
\hline 年平均 & & 33 & 42 & 53 & 72 & 53 & 71 & 82 & 41 \\
\hline Strd. & & 33 & 39 & 40 & 66 & 50 & 60 & 60 & 62 \\
\hline
\end{tabular}

また市内家庭料理のKは第5 丧のと扣りであり，主食 系, 皿物, 汁物系統の食品類别に特徴があることがわか る。

第5表の Kvilamin は一般に低くビタミン被補給食的 であり第 4 表のそれが供給全的であることも明かであ る。1日の全食事についてはすへべての $K$ が 1 であるよう な献立にはむだがないといえるのであるが 1 日 1 食の学 給それ自体は $K_{x}=1$ である必要はなく，むしろ補給食 
栄䍩と食糧

第 4 表献立 の栄盖平衡係数

\begin{tabular}{|c|c|c|c|c|c|c|c|c|}
\hline 種別 & 月 & 番号 & 理 名 & & $K_{p}$ & $K_{f}$ & $K_{B_{1}}$ & $K_{B_{2}}$ \\
\hline 1 & \multirow[t]{15}{*}{4} & 1 & パ & ン & 1.1 & 1 & 3 & 1.9 \\
\hline 2 & & & $ミ \quad ル$ & $\eta$ & 3.3 & 0.3 & 1.7 & 9.5 \\
\hline 3 & & & カ $レ$ シチュ & - & 1 & 3 & 2. 7 & 1.7 \\
\hline 4 & & 2 & ス $\quad$ チ ッ & ク & 1.8 & 4.8 & 4.2 & 0.2 \\
\hline 5 & & & ポ ター シ & ב & 2 & 2. 5 & 12 & 5.5 \\
\hline 6 & & 3 & $\Xi-ト y-x$ & 煮 & 0.9 & 2.3 & 0.9 & 0.1 \\
\hline 7 & & 4 & 鰂のかん & 煮 & 3 & 6.3 & 0.8 & 0.3 \\
\hline 8 & & & ソ $\quad$ テ & - & 2 & 1 & 5 & 15 \\
\hline 9 & & 5 & 含ま せ & 煮 & 2.4 & 3 & 1. 2 & 0.6 \\
\hline 10 & & 6 & 炒＼cjkstart合 & 荣 & 1. 3 & 5 & 3.7 & 5.7 \\
\hline 11 & & 7 & マッシュポテ & $r$ & 1 & 3.7 & 1. 8 & 0.9 \\
\hline 12 & & 8 & いそべ揚 ! & ザ & 1. 3 & 5.6 & 0.6 & 0.6 \\
\hline 13 & & & み そ & 汁 & 4 & 2.5 & 12.5 & 13 \\
\hline 14 & & 9 & ぶ & 豆 & 2.1 & 2. 4 & 1.7 & 0.7 \\
\hline 15 & & & ごま ま & 煮 & 1 & 4 & 5 & 14 \\
\hline 16 & \multirow[t]{19}{*}{6} & 1 & マ 一 ガ リ & ン & 0 & 8 & 0 & 0 \\
\hline 17 & & 2 & $\beth \beth \quad\ulcorner\quad ル$ & ク & 3.3 & 0.3 & 1. 8 & 9.5 \\
\hline 18 & & & カ $v-y-x$ & 煮 & 1. 1 & 2.9 & 0.9 & 0.3 \\
\hline 19 & & 3 & イ チ ゴジ + & 么 & 0 & 0 & 14 & 14 \\
\hline 20 & & & 酢 & 鯨 & 2 & 4.3 & 0.9 & 0.5 \\
\hline 21 & & 4 & 親＜wide>于 & 暗 & 1. 6 & 3.8 & 1.8 & 2.4 \\
\hline 22 & & 5 & ちくわの照 & 煮 & 2. 3 & 2 & 0.7 & 1 \\
\hline 23 & & & $\nabla \quad \quad ッ \quad$ シ & ב & 1. 3 & 4.7 & 2 & 2 \\
\hline 24 & & $\sigma$ & 炒 り & 卵 & 2.8 & 5.8 & 1. 3 & 3 \\
\hline 25 & & & ソ $\quad$ テ & - & 1 & 11 & 4 & 13 \\
\hline 26 & & 7 & オ レ ン シ シ & 么 & 0 & 0 & 9 & 6 \\
\hline 27 & & & あ じ フ ラ & イ & 1. 7 & 4 & 1 & 0.3 \\
\hline 28 & & 8 & 煮 & 豆 & 1. 6 & 0.3 & 2.1 & 0.4 \\
\hline 29 & & & 市 九 か & け & 2.3 & 2.7 & 1. 7 & 1 \\
\hline 30 & & 9 & 洋風 & 煮 & 1. 3 & 0.2 & 1. 7 & 2 \\
\hline 31 & & 10 & じゃがいもの甘 & 煮 & 1 & 3. 4 & 2.2 & 0.6 \\
\hline 32 & & 11 & ポークビーン & ズ & 1. 1 & 3 & 1. 6 & 0.4 \\
\hline 33 & & 13 & り ん ごジ + & 厶 & 0 & 0 & 9 & 6 \\
\hline 34 & & & ツ $\quad$ V & ツ & 1.7 & 5 & 0.6 & 0.4 \\
\hline 35 & \multirow[t]{6}{*}{7} & 1 & クロ ケッ & ト & 1 & 3.6 & 0.3 & 0.3 \\
\hline 36 & & & ト & ト & 0 & 0 & 0 & 0 \\
\hline 37 & & 2 & $\begin{aligned} \text { スパゲティの } & \text { ミートソースか } \\
& \text { ミートー }\end{aligned}$ & & 1 & 3.4 & 0.7 & 0.1 \\
\hline 38 & & 4 & 七 宝 豆 & 應 & 1.1 & 5.9 & 0.6 & 0.1 \\
\hline 39 & & 6 & 空市 & ザ & 0.4 & 5.4 & 1 & 0.4 \\
\hline 40 & & 7 & ソーセージのソテ & - & 1. 4 & 6.4 & 1. 6 & 0.6 \\
\hline
\end{tabular}

的な意味があるほうがよい。本来ならば学童の朝夕食に ついて食事調査を実施して，そのKがミ1のばあいに， これを学給によって正しく補正し $K \geqq 1$ にするための調 查システムが存在することが望ましい。

なお学給基準献立第 1 表から $K$ 值を求めると第 6 表が

えられる。

4. 栄養平衡性の図化

第 1 図は $f_{x}$ による学給基準献立の平衡関係図である。 昭和37年に改正された現行の基準型はそれ以前の型に比 ベて $f_{C a}$ および $f_{A}$ において減少し, $f_{f a t}, f_{\text {oal }}$ 
第 5 表 一般家涏の N. B. C.

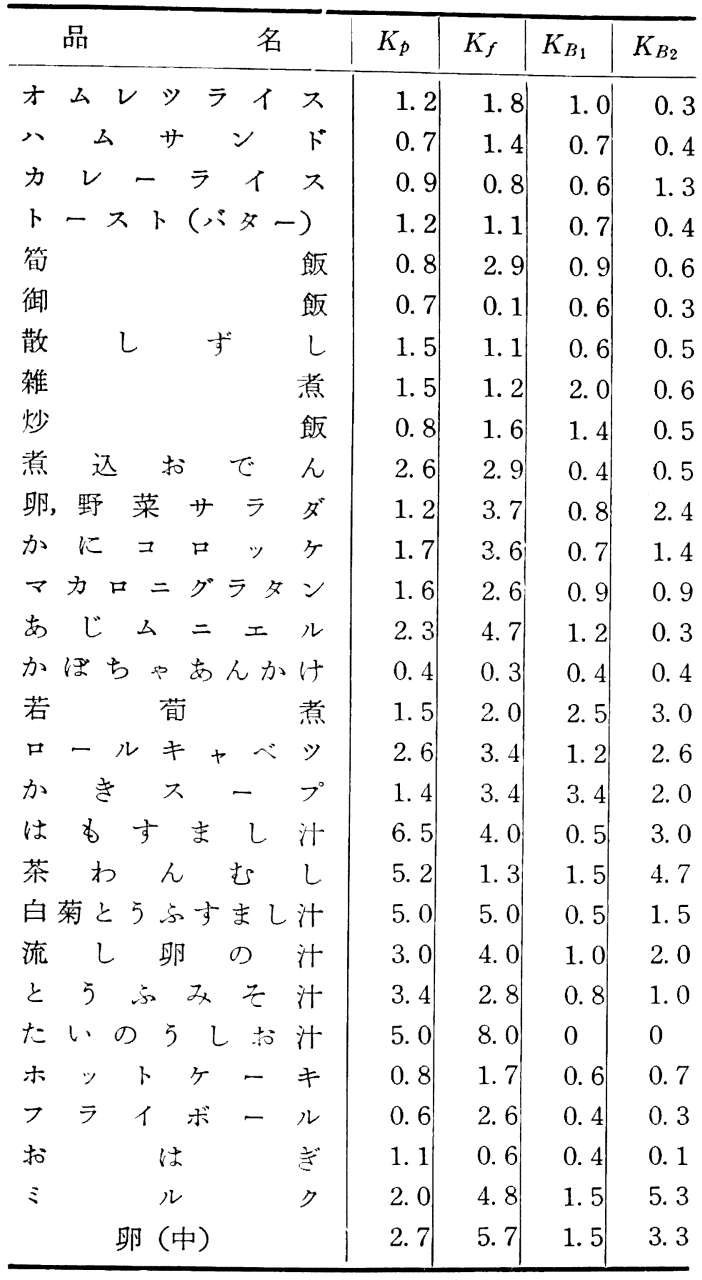

第 6 表 学給基準の N.B.C.

\begin{tabular}{c|c|c|c|c|c|c|c}
\hline$K$ & $K_{p}$ & $K_{f}$ & $K_{B_{1}}$ & $K_{B_{2}}$ & $K_{A}$ & $K_{C}$ & $K_{C a}$ \\
\hline 36 年度 (6〜11才) & 1.5 & 1.4 & 1.9 & 1.9 & 3.1 & 1.3 & 3.5 \\
\hline 37 " $(9 \sim 11$ " $)$ & 1.4 & 1.4 & 1.6 & 1.6 & 1.8 & 2.2 & 2.4 \\
\hline 37 " $(6 \sim 8$ " $)$ & 1.4 & 1.4 & 1.9 & 1.9 & 1.3 & 1.9 & 2.1 \\
\hline
\end{tabular}

$f_{\text {prot }}$ および $f_{C}$ に掞いて增大し均衡のとれた図形にな っている。

このようにわれわれの方法では平衡関係の特色を直視 することが可能である。例えば 4 月献立を平衡図で示す と第 2 図のと扣りであって基準図形に比べてかなり不均 衡な内容をもっていることがわかる。特に $f_{C}$ の項では 不良である。

$f_{c}$ の欠点を改良するために教育委員会ではその後 12
のであるが，11月と12月の 2 カ月にわたる，この際の平 衡関倸図上に拉ける变化は第 3 図のように䛠みとること ができる。

\section{5. 蛋白価の算出}

第 7 表はわれわれの計算法で算出した学給献立の蛋白 価表である。

アメリカ人の食糧では 85 , 日本人一般では73であるの に比べて，この献立の数值ではなお一榞努力を要するこ とが明かであり，またかなり数值にムラがあることがわ かる。なおミルクを欠いた献立では蛋白価は60代にさが ることも注意すべきである。逆にい党ば今日の学給では ミルクにての主たる蛋白の供給を依存して拈り，副食血 物の質があまりよいとはいえないことも指摘されればな らない。

パンとミルクだけによる蛋白価は84であるから，少な くともこれを下回らない程度の副全を準侕すべきであっ て，その意味でも単なる動物性蛋白量の記载に止らず， 今後は蛋白価も明記することが必要である。

6. アミノ酸平衡性の解析と図化

第IX報 ${ }^{9}$ ，第 4 図に日本人とアメリカ人飭糧のアミ， 酸平衡図を示し，同じく第 5 図に学給献立の一部の図形 を示したが現行献立ではパンとミルクだけの平衡図形よ り 6献立全体としての図形の方か内容的に低質化してい るばあいがある。また同じ玵報”にに示したと打り $p, r$ 值の大きさもなお満足与べきものとはいてない。今後さ らに獣魚など肉類を多用する工夫がなければならないで あ万5。

7. 献立作整の能京化

第 4 図は昭和 37 年度学給献立の全料理を記号化し, 相 当与る F. N.C. 值の位置に記入して，奏除に作図した F. N.C. 栄兴部算尺である。組み合扣せ法によって基準

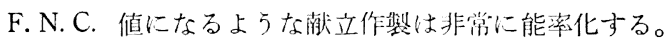
また四報 ${ }^{8}$ 第 1 汹にコスト計算尺の模式䦷を示した。

8. 栄羡係数献立表

以上の各項を参照して今後の献立表としては，現行の 献立表のような絶対值を記した原表のほかに，われわれ の方式に従って

(1) F. N. C. 数值を用い

(2) E. N. C. 值を記載し

(3) 栄養平衡図形を記し

(4) アミノ酸平衡図形を示し

（5）蛋白価を明記した，例えば第 8 表のよ5な献立表 を準備すべきである。

結 論 
第 1 図 児童 1 人 1 回当たりの平均所要栄溒量の基準

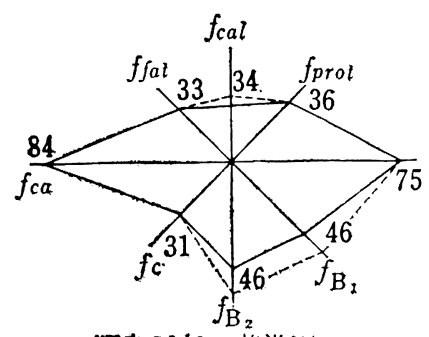

昭和 36 年の基準型

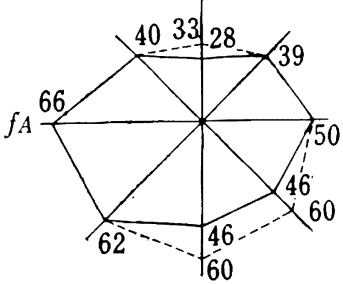

昭和37年の基準型

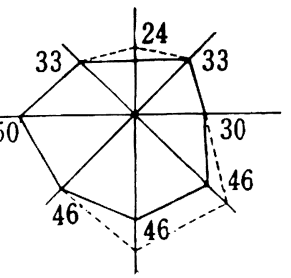

同じく $\quad \stackrel{\pi}{6}$ - 8才

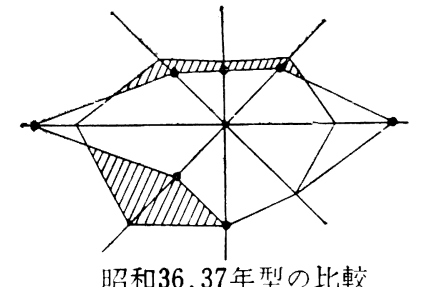

点線 9 ～11才児童基準

寒線 成人男子"

第 2 因 4 月献立の平衡関係図

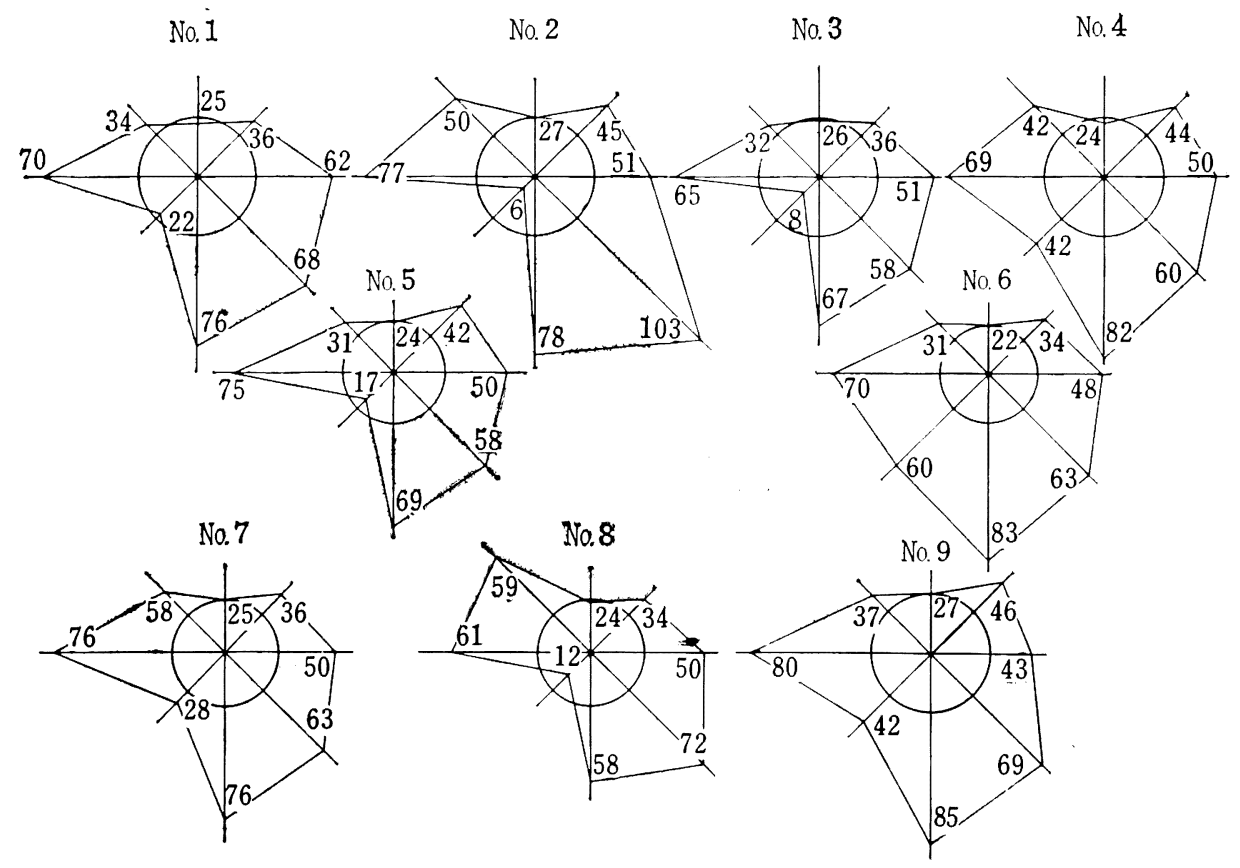


第 17 巻 第 4 号

第 3 図 11〜12月献立の平衡関倸図
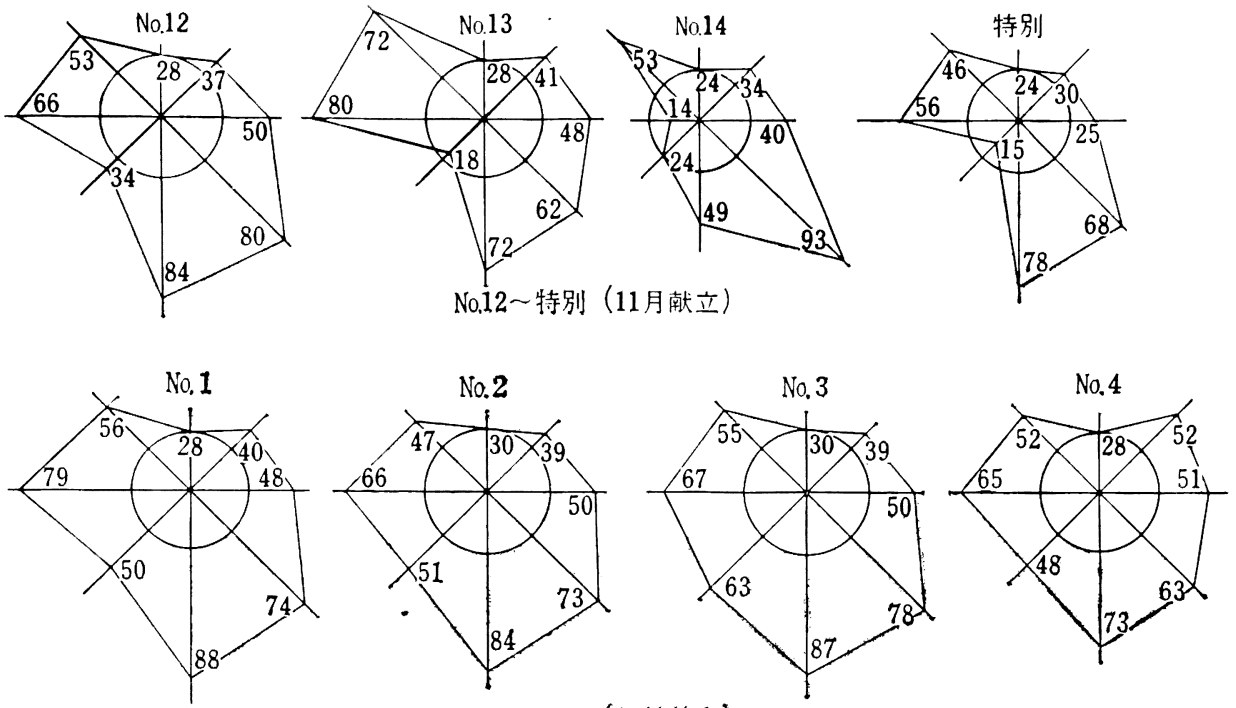

No. $1 \sim$ No. 4 (12月献立)

第 7 表京都市学校給食の蛋白洒（昭和 37 年）

\begin{tabular}{|c|c|c|c|c|c|c|c|c|c|c|c|c|c|c|c|c|}
\hline 種 & 1 & 2 & 3 & 4 & 5 & 6 & 7 & 8 & 9 & 10 & 11 & 12 & 13 & 14 & 15 & 平均 \\
\hline 4月 & 83 & 83 & 85 & 78 & 76 & 78 & 83 & 67 & 88 & & & & & & & 80 \\
\hline 5月 & 83 & 85 & 83 & 91 & 78 & 75 & 88 & & 72 & 75 & 81 & 63 & & & & 79 \\
\hline 6月 & 81 & 85 & 74 & 87 & 85 & 92 & 87 & 66 & 81 & 81 & 78 & 83 & 60 & & & 80 \\
\hline 7月 & & 84 & 74 & 69 & 81 & 82 & 81 & & & & & & & & & 79 \\
\hline 9月 & 83 & 81 & 82 & 81 & 72 & 73 & 81 & 54 & 67 & 78 & & & & & & 75 \\
\hline 10月 & 80 & 81 & 82 & 80 & 73 & 83 & 85 & 81 & 69 & 87 & 73 & 73 & 81 & & & 79 \\
\hline 11月 & 80 & 73 & 87 & 81 & 86 & 65 & 73 & 78 & & 87 & & 84 & 69 & 115 & & 82 \\
\hline 12 月 & 80 & 83 & 90 & 78 & 81 & 70 & 86 & 72 & 78 & 64 & & & & & & 78 \\
\hline 1月 & 84 & 84 & & 81 & & 80 & 75 & 70 & 79 & & & & & & & 79 \\
\hline 2月 & 81 & & 80 & 76 & 67 & 81 & . & & 80 & 79 & & 83 & & & & 78 \\
\hline 3月 & 71 & 74 & 80 & 80 & 65 & & 76 & 81 & & & & & & & & 75 \\
\hline
\end{tabular}

第 8 表 栄埕 係 数 献立表

\begin{tabular}{|c|c|c|c|c|c|c|c|c|c|c|c|c|c|c|}
\hline 月 & 献立名| & 対照 & $f_{\text {cal }}$ & $f_{\text {prot }}$ & $f_{f a t}$ & $f_{c . H}$ & $f_{C a}$ & $f_{A}$ & $f_{B_{1}}$ & $f_{B_{2}}$ & $f_{c}$ & 平衡関倸図 & アミノ酸平衡図 & 蛋白価 \\
\hline \multirow{4}{*}{ No. } & A & & & & & & & & & & & & & \\
\hline & B & & & & & & & & & & & & & \\
\hline & \multicolumn{2}{|c|}{$\sum f_{x}$} & & & & & & & & & & & & \\
\hline & $E$ & & & & & & & & & & & & & \\
\hline
\end{tabular}



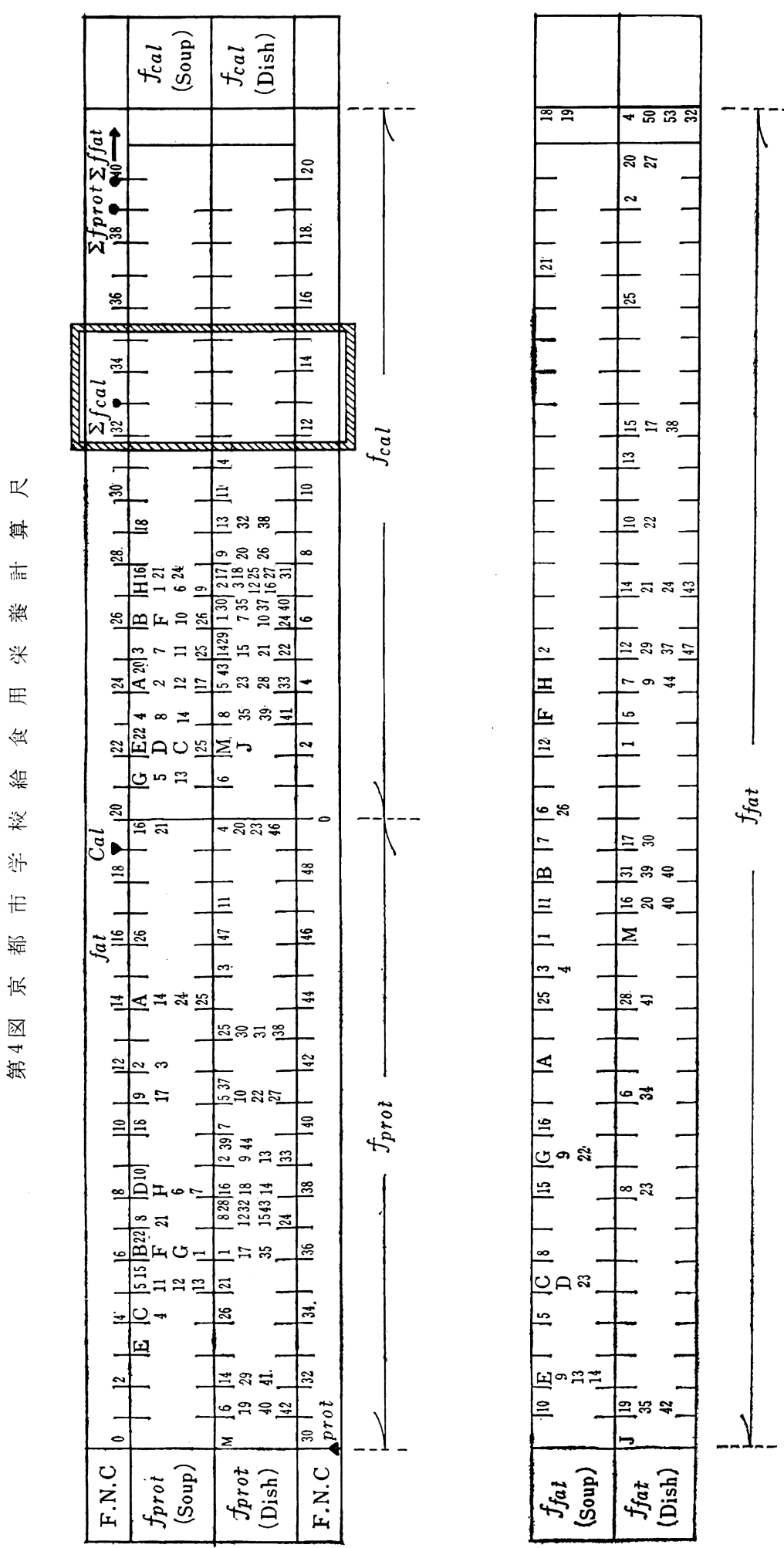

われわれが前 9 報にのべた栄 養係数諭にもとつくく献立解析の 方法は，本報に怙いて京都市学 校給食の解析に適用された結果 従来ややもすれば典型的献立と の単なる類比にとどまりがちで あった献立立案もしくは評価の 仕方を，栄盖学的知見に従って より精密な数值を媒体として考 えなおしあるいは图形として みなおすため打有用であること が明かになったといえよう。

学給献立についてはさらに基 本的に，文部省の基準量によら ず，その地域の体位，もしくは 目標とする体位にもとつく府, 罧, 市など地域独自の找取基準 栄盖量を設けるべきであり，そ のほか問題点は多いのであるが 少なくとも献立解析の手法とし ては本論の方法が現状では要を つくすものと考えたい。

な扮本論のも5ひとつの目的 である京都市昭和 37 年度学給献 立の評価については各論にのぺ たのでここには再揭しないが， 関係各位の献立作彆に注がれた なみなみなら㚵力のあとが偲 ばれると共に, われわれの方法 によってな括仔細に検討すれば 今後に残された課題もまた多い ことも明かである。

終りにあたり関係資料を提供 された, 京都市教委, 学校保健 課合田博課長, 島田由贵子栄養 士に厚く御礼申上げます。

$$
\text { 文献 }
$$

1）藤原, 福原 : 栄養と食 糧, 16, 82 (1963)

2) 同上, 16, 87 (1963)

3) 同 上, 16, 168(1963)

4) 同 上, 16, 171(1963)

5) 同 上, 16, 531(1964)

6) 同 上, 16, 535(1964)

7) 同 上, 17, 91 (1964)

8) 同 上, 17, 93 (1964)

9) 同 上, 17, 169(1964) (京都市衛生研究所) 